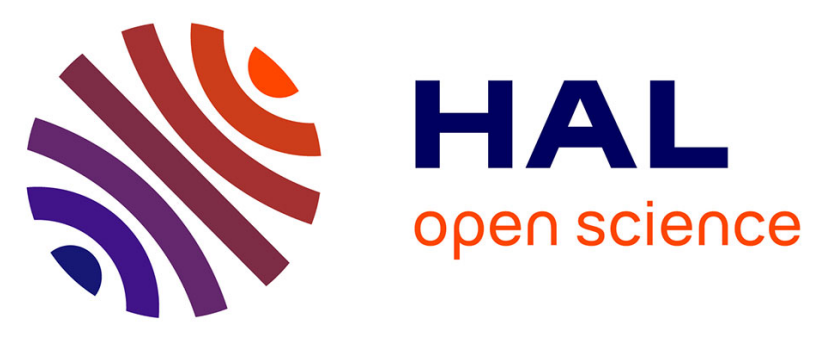

\title{
A leucine supplementation after an immobilization-induced atrophy in old rats enhanced protein anabolism but failed in muscle mass recovery
}

Hugues Magne, Isabelle Savary-Auzeloux, Claire Sornet, Carole Migné, Lydie Combaret, Dominique Dardevet

\section{To cite this version:}

Hugues Magne, Isabelle Savary-Auzeloux, Claire Sornet, Carole Migné, Lydie Combaret, et al.. A leucine supplementation after an immobilization-induced atrophy in old rats enhanced protein anabolism but failed in muscle mass recovery. 8. International Symposium on Amino Acid and Protein Metabolism in Health and Disease, European Society of Parenteral and Enteral Nutrition (ESPEN). LUX., 2013, 10.1016/j.numecd.2013.10.004 . hal-02744978

\section{HAL Id: hal-02744978 \\ https://hal.inrae.fr/hal-02744978}

Submitted on 3 Jun 2020

HAL is a multi-disciplinary open access archive for the deposit and dissemination of scientific research documents, whether they are published or not. The documents may come from teaching and research institutions in France or abroad, or from public or private research centers.
L'archive ouverte pluridisciplinaire HAL, est destinée au dépôt et à la diffusion de documents scientifiques de niveau recherche, publiés ou non, émanant des établissements d'enseignement et de recherche français ou étrangers, des laboratoires publics ou privés. 


\section{Abstracts of the 8th International Symposium Amino Acid/Protein Metabolism in Health and Disease}

\section{Metabolic pathways and local progenitor activation to regulate skeletal muscle mass}

ROLE OF VITAMIN D IN THE PATHOGENESIS OF MUSCLE WASTING IN CANCER CACHEXIA

A. Camperi, F. Penna, D. Costamagna, F. M. Baccino, M. Muscaritoli, P. Costelli

Department of Experimental Medicine and Oncology, University of Turin, Italy

Cancer cachexia is a syndrome characterized by loss of skeletal muscle protein, depletion of lipid stores and hormonal perturbations. Vitamin D (VitD) has been recently proposed as a potential regulator of skeletal muscle tissue since several studies described a relationship between muscle weakness/wasting and vitamin $D$ deficiency.

Preliminary data obtained in our laboratory indicated a significant decrease in circulating VitD in rats bearing the $\mathrm{AH}-130$ hepatoma compared to controls. On this line, the aim of the present study was to investigate the involvement of $\mathrm{Vit} \mathrm{D}$ deficiency in the pathogenesis of muscle wasting in $\mathrm{AH}-130$ bearing rats. Rats were divided into four experimental groups: control, $\mathrm{AH}-130$, VitD-treated and AH-130 VitD-treated. VitD (calcitriol, 1,250H VitD) was administered daily per os ( $5 \mu \mathrm{g} / \mathrm{kg}$ initial body weight, dissolved in corn oil). Untreated groups received vehicle alone. Treatment started the day of tumor transplantation and the animals were sacrificed after 7 days.

Both VitD-treated groups (controls and tumor hosts) showed reduced body weight and decreased GSN and tibialis mass in comparison to the respective untreated groups. Although preliminary, these results apparently suggest that VitD administration does not prevent tumor-induced muscle wasting. Such observation might be consistent with results obtained on $\mathrm{C} 2 \mathrm{C} 12$ myocyte cultures, where the presence of calcitriol in the culture medium impairs myoblast complete differentiation to myotubes, suggesting that VitD-activated signals might inhibit myogenesis.

THERAPEUTIC PARACETAMOL TREATMENT IN OLDER PERSONS INDUCES DIETARY AND METABOLIC MODIFICATIONS RELATED TO SULFUR AMINO ACIDS

E. Pujos-Guillot ${ }^{1}$, G. Pickering ${ }^{2}$, B. Lyan ${ }^{1}$, G. Ducheix ${ }^{2}$,

M. Brandolini-Bunlon ${ }^{3}$, F. Glomot ${ }^{4}$, D. Dardevet ${ }^{4}$, C. Dubray ${ }^{2}$, I. Papet ${ }^{4}$ ${ }_{1}^{1}$ Plateforme d'Exploration du Métabolisme, INRA, Centre Clermont-Ferrand Theix, UMR 1019 Nutrition Humaine, Saint-Genès-Champanelle, F-63122, France

${ }^{2}$ Centre de Pharmacologie Clinique, Inserm CIC 501, INSERM U766, Faculté de Médecine, Clermont-Ferrand, F-63003 France

${ }^{3}$ CRNH Auvergne, Unité d'Exploration en Nutrition, Clermont-Ferrand, F-63003, France

${ }^{4}$ INRA, Centre Clermont-Ferrand - Theix, UMR 1019 Unité de Nutrition Humaine, F-63122 Saint-Genès-Champanelle, France, Univ Clermont 1, UFR
Médecine, UMR1019, Unité Nutrition Humaine, F-63001 Clermont-Ferrand, France

Sulfur amino acids are determinant for the detoxification of paracetamo ( $\mathrm{N}$-acetyl-p-aminophenol) through sulfate and glutathione conjugations. Long term paracetamol treatment is common in elderly, despite a potential cysteine/glutathione deficiency. Detoxification could occur at the expense of anti-oxidative defenses and whole body protein stores in elderly. We tested how older persons satisfy the extra demand in sulfur amino acids induced by long term paracetamol treatment, focusing on metabolic and nutritional aspects. Effects of $3 \mathrm{~g} / \mathrm{d}$ paracetamol for 14 days on fasting blood glutathione, plasma amino acids and sulfate, urinary paracetamol metabolites, and urinary metabolomic were studied in independently living older persons (five women, five men, mean ( \pm SEM) age $74 \pm 1 \mathrm{y}$ ). Dietary intakes were recorded before and at the end of the treatment and ingested sulfur amino acids were evaluated. Fasting blood glutathione, plasma amino acids and sulfate were unchanged. Urinary nitrogen excretion supported a preservation of whole body proteins, but large scale urinary metabolomic analysis revealed an oxidation of some sulfur-containing compounds. Dietary protein intake was $13 \%$ higher at the end than before paracetamol treatment. Final sulfur amino acid intake reached $37 \mathrm{mg} / \mathrm{kg} / \mathrm{d}$. The quantity of sulfur excreted in urinary paracetamol conjugates corresponded to $20 \%$ of the dietary intake in sulfur amino acids. Older persons accommodated to long term paracetamol treatment by increasing dietary protein intake without any mobilization of body proteins, but with increased oxidative damages. The extra demand in sulfur amino acids led to a consumption far above the corresponding population-safe recommendation.

A LEUCINE SUPPLEMENTATION AFTER AN IMMOBILIZATION-INDUCED ATROPHY IN OLD RATS ENHANCED PROTEIN ANABOLISM BUT FAILED IN MUSCLE MASS RECOVERY

Hugues Magne ${ }^{1,2}$, Isabelle Savary-Auzeloux ${ }^{1,2}$, Claire Sornet ${ }^{1,2}$, Carole Migné ${ }^{1,2}$, Lydie Combaret ${ }^{1,2}$, Dominique Dardevet ${ }^{1,2}$ 1 INRA, UMR 1019 Human Nutrition Unit, F-63122 Saint Genès Champanelle, France

${ }^{2}$ Univ Clermont 1, UFR Médecine, UMR 1019 Nutrition Humaine, F-63000 Clermont-Ferrand, France

Background: By contrast to adult, we have shown (Magne et al. 2011) that immobilization during ageing generated muscle atrophy which is not recov ered. This is not due to a sustained muscle proteolysis since it was rapidly normalized. This study was undertaken to assess if an alteration of muscle protein synthesis during the immobilization and the recovery periods was involved and if a leucine supplementation may improve muscle mass following immobilization. 
hods: 23 -month-old rats were immobilized for 8 days (18) and allowed to recover during 40 days. Half of the rats received a control diet whereas the other half were fed the same diet supplemented with $4.5 \%$ leucine after cast removal. Muscle proteasome-dependent proteolytic activities, FOXO3aphosphorylation were assessed in gastrocnemius. Protein synthesis and protein $\mathrm{S} 6$ phosphorylation were measured at both the postabsorptive (PA) and post prandial (PP) states

Results: At 18, immobilized-muscles were atrophied by $21 \%$ that was explained by an increased proteasome activities $(+20$ to $+80 \%)$ but also by a large decreased in protein synthesis at PP $(-30 \%)$. During recovery, proteolysis and protein synthesis were normalized. With the leucine-diet, proteolysis was normalized earlier and protein synthesis was 30\% higher in PP than in controls. These observations were correlated with an increased phospho-FOXO3a/FOXO3a ratio $(+80 \%)$ and a sustained increase of phospho-S6 amount $(+30 \%)$ However, despite this improvement of muscle anabolism, leucine failed to improve muscle mass recovery.

Conclusion: After immobilization, leucine supplementation, despite its beneficial effect on muscle protein anabolism failed in muscle mass recovery. This discrepancy needs to be further studied.

\section{DIFFERENTIAL INSULIN SIGNALING REGULATION IN SKELETAL MUSCLE AND ADIPOSE TISSUE FROM OLD RATS FED A LONG-TERM LEUCINE EXCESS}

Gilbert Zeanandin ${ }^{1}$, Michèle Balage ${ }^{2}$, Claire Sornet ${ }^{2}$, Joëlle Dupont ${ }^{3}$, Stéphane M. Schneider ${ }^{1}$, Isabelle Mothe-Satney ${ }^{1}$, Dominique Dardevet ${ }^{2}$ ${ }^{1}$ Centre Hospitalier Universitaire de Nice, Pôle Digestif, Nice F-06202, France; Université de Nice-Sophia Antipolis, Faculté de Médecine, Nice F-06107; INSERM, U907, IFR50, Nice F-06107, France

2INRA, Centre Clermont-Ferrand - Theix, UMR 1019, Unité Nutrition Humaine, F-63122 Saint Genes Champanelle; Univ Clermont 1, UFR Médecine, UMR 1019 Unité Nutrition Humaine, F-63001Clermont-Ferrand, France

${ }^{3}$ INRA, UMR 85 Physiologie de la Reproduction et des Comportements, F-37380 Nouzilly, France

Leucine acts as a signal nutrient in promoting protein synthesis in skeletal muscle and adipose tissue via mTOR/S6K1 pathway activation, and may be of interest to prevent age-related sarcopenia. However, hyper-activation of mTOR/S6K1 has been suggested to inhibit the first steps of insulin signaling and finally promote insulin resistance.

The impact of long-term dietary leucine supplementation on insulin signaling and sensitivity was investigated in old rats (18-month old) fed a $15 \%$ protein diet supplemented (LEU group) or not (C group) with $4.5 \%$ leucine for 6 months. The resulting effects on muscle and fat were examined.

mTOR/S6K1 signaling pathway was not significantly altered in muscle from old rats subjected to long-term dietary leucine excess whereas it was increased in adipose tissue. Phosphorylation of IRS1 on serine 635/636 was increased in adipose tissue but not in muscle. Overall glucose tolerance was not changed but insulin-stimulated glucose transport was improved in muscles from leucine-supplemented rats related to improvement in Akt expression and phosphorylation in response to food intake. No change in skeletal muscle mass was observed whereas perirenal adipose tissue mass accumulated $(+45 \%)$ in leucine-supplemented rats.

A prolonged leucine supplementation in old rats differently modulates IR/IRS/Akt and mTOR/S6K pathways in muscle and adipose tissue. It does not increase muscle mass but seems to promote hypertrophy and hyperplasia of adipose tissue that did not result in insulin resistance.

\section{HYPERCYST(E)INEMIA IN CDO ${ }^{-/-}$MOUSE MODEL IS ASSOCIATED WITH AN ACCUMULATION OF TISSUE ACID-LABILE SULFIDE AND LOW CIRCULATING HOMOCYSTEINE LEVELS}

A. Valli, L. L. Hirschberger, H. B. Roman, M. H. Stipanuk

Division of Nutritional Sciences, Cornell University, Ithaca NY 14853, USA

Cysteine (Cys) is considered a semi-essential amino acid in mammals as it is synthesized via transsulfuration of homocysteine (Hcy) by two enzymes, cystathionine $\beta$-synthase (CBS) and cystathionine $\gamma$-lyase (CSE). Cysteine can be oxidized by cysteine dioxygenase (CDO) to taurine and sulfate. Nonoxidative desulfuration reactions mediated by CBS and CSE can transform cysteine to reduced sulfur, generating endogenous $\mathrm{H}_{2} \mathrm{~S}$. Cysteine is also used for the synthesis of glutathione $(\mathrm{GSH})$ a reduced tripeptide that also contains glutamate and glycine. To gain more insight into the physiological control of cysteine metabolism, functions of $\mathrm{CDO}$ and the consequences of a loss of $\mathrm{CDO}$ activity, we generated $\mathrm{CDO}^{-/-}$and $\mathrm{CDO}^{+/+}$mice. Because of the disruption of flux through $\mathrm{CDO}$-dependent pathways, $\mathrm{CDO} \mathrm{O}^{-/-}$ an increase in serum cyst(e)ine levels compared to $\mathrm{CDO}^{+/+}$mice. Surprising y serum $\mathrm{Hcy}$ levels markedly decreased in $\mathrm{CDO}^{-1-}$ compared to $\mathrm{CDO}^{+/+}$mice. Serum Cys levels were positively associated with tissue acid-labile sulfide levels. The association of Cys with $\mathrm{GSH}$ was slightly positive in $\mathrm{CDO}^{+/+}$ mice whereas no association was found in $\mathrm{CDO}^{-1-}$ mice. Treatment of $\mathrm{CDO}^{-1-}$ mice with a taurine-supplemented diet decreased tissue acid-labile sulfide and $\mathrm{GSH}$ levels compared to non-taurine treated $\mathrm{CDO}^{-1-}$ mice. On the other hand, serum Hcy levels increased in taurine treated $C D O^{-1}$ mice when compared to non-taurine treated $\mathrm{CDO}^{-1-}$ mice. Taken all together these results suggested that in the absence of CDO cysteine is preferentially metabolized via desulfuration pathways with only a small increase in net flux to glutathione. The increase in tissue acid-labile sulfide levels and the decrease of the serum Hcy level in $C^{-1-}$ mice suggest the idea that serum hypercyst(e)inemia could lead to increased flux of cysteine through the reactions catalyzed by CBS and CSE (enzymes involved in both desulfuration and transsulfuration), resulting in an increase of $\mathrm{H}_{2} \mathrm{~S}$ accumulation in tissues and a reduction in circulating Hcy levels.

\section{COMBINED APPROACH TO COUNTERACT EXPERIMENTAL CANCER} CACHEXIA: EICOSAPENTENOIC ACID AND TRAINING EXERCISE

Fabio Penna ${ }^{1}$, Silvia Busquets ${ }^{2}$, Fabrizio Pin ${ }^{1}$, Miriam Toledo ${ }^{2}$ Francesco M. Baccino ${ }^{1}$, Francisco J. López-Soriano ${ }^{2}$, Paola Costelli ${ }^{1}$, Josep M. Argilés ${ }^{2}$

${ }^{1}$ Department of Experimental Medicine and Oncology, University of Torino, Italy

${ }^{2}$ Departament de Bioquímica i Biologia Molecular, Facultat de Biologia, Universitat de Barcelona, Barcelona, Spain

Cancer cachexia is a syndrome characterized by loss of skeletal muscle protein, depletion of lipid stores, anorexia, weakness, and perturbations of the hormonal homeostasis. Despite several therapeutic approaches were described in the past, effective interventions countering cancer cachexia are still lacking.

The aim of the present work was to verify the ability of eicosapentaenoic acid (EPA) to prevent the muscle depletion in Lewis lung carcinoma-bearing mice and to test the ability of exercise training to increase the EPA effect. EPA alone did not prevent the muscle loss induced by tumor growth, while the combination with the exercise induced a partial rescue of muscle strength and mass. Moreover, the association of EPA and exercise reduced the dramatic PAX-7 accumulation and stimulated the increase of PCG-1 protein.

Overall, the present data suggest the exercise as an effective tool that should be added on combined therapeutic approaches against cancer cachexia.

\section{HYPERINSULINEMIA AND INSULIN RESISTANCE, EARLY CARDIOVASCULAR RISK FACTORS IN CHILDREN WITH CHRONIC KIDNEY DISEASE}

Ylva Tranæus Lindblad a , Jonas Axelsson ${ }^{\mathrm{b}}$, Peter Bárány ${ }^{\mathrm{b}}$, Gianni Celsi ${ }^{\mathrm{a}}$, Bengt Lindholm ', Abdul Rashid Qureshi ', Alba Carrea d, Alberto Canepa ' ${ }^{a}$ Division of Pediatrics, Intervention and Technology at Karolinska Institute and Karolinska University Hospital Huddinge, Stockholm, Sweden

${ }^{b}$ Division of Renal Medicine, Intervention and Technology at Karolinska Institute and Karolinska University Hospital Huddinge, Stockholm, Sweden ${ }^{c}$ Division of Baxter Novum and Department of Clinical Science, Intervention and Technology at Karolinska Institute and Karolinska University Hospital Huddinge, Stockholm, Sweden

${ }^{d}$ Department of Pediatric Nephrology, Institute G. Gaslini, Genoa, Italy

Background/aims: Pediatric chronic kidney disease (CKD) is associated with increased risk of cardiovascular disease. Still, hyperinsulinemia and insulin resistance, common cardiovascular risk factors, are not extensively investigated in children with CKD. We hypothesize that insulin abnormalities are present also in pediatric mild to moderate CKD, and associated with inflammation and malnutrition.

Methods: We enrolled 26 children with CKD, and 34 healthy controls for analyses of blood samples and body composition. Insulin resistance was assessed using the homeostasis model assessment for insulin resistance (HOMA-IR).

Results: The patients had higher insulin levels and HOMA-IR compared to the controls ( $p<0.01$ and $p<0.005)$, and they correlated inversely with estimated glomerular filtration rate (rho $=-0.52, \mathrm{p}<0.01$; rho $=-0.37$, $\mathrm{p}=0.08)$. No association was found with inflammation or malnutrition. Conclusion: High insulin levels and HOMA-IR appear to be common in pediatric CKD patients, already in mild to moderate renal failure. We 